\title{
Thoracic pseudotumours: a pictorial essay
}

\author{
S De Luca*, C Carrera, A Zanfardini, L Tolkachier, D Pascuzzi, E Eyheremendy \\ From International Cancer Imaging Society Meeting and 15th Annual Teaching Course (ICIS 2015) \\ London, UK. 5-7 October 2015
}

\section{Learning objectives}

Imaging appearance of primary lung tumour conditions that on initial radiological studies might be confused with malignant lesions.

\section{Content organisation}

Diagnostic tools for evaluation of thoracic tumours and pseudotumours. We included in the differential diagnosis:

Paraffinoma (1), a hydatid cyst (1), inflammatory pseudotumour (3), nodular tuberculosis (2) and sarcoidosis granulomas (1), round pneumonia (1), nodular criptococosis (1), post-surgical or tuberculosis scarring processes (2), organising cryptogenetic pneumonia (2) and round atelectasis (3).

\section{Conclusion}

There are several diseases that can mimic tumours of the chest. It is necessary to take them into account and know how to use diagnostic keys for an accurate diagnosis.

Published: 2 October 2015

doi:10.1186/1470-7330-15-S1-P26

Cite this article as: De Luca et al.: Thoracic pseudotumours: a pictorial essay. Cancer Imaging 2015 15(Suppl 1):P26.

\footnotetext{
* Correspondence: sdeluca@hospitalaleman.com
} Hospital Aleman, Buenos Aires, Argentina

Submit your next manuscript to BioMed Central and take full advantage of:

- Convenient online submission

- Thorough peer review

- No space constraints or color figure charges

- Immediate publication on acceptance

- Inclusion in PubMed, CAS, Scopus and Google Scholar

- Research which is freely available for redistribution 